研 究

\title{
$\left(\mathrm{CeO}_{2}\right)_{1-\mathrm{x}}\left(\mathrm{YO}_{1.5}\right)_{x}$ の合成と弾性特性の評価に関する研究
}

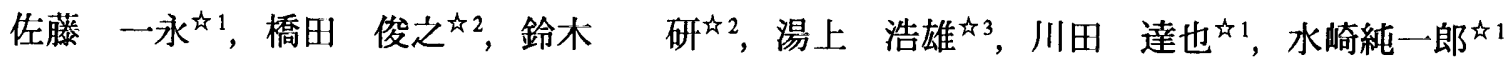 \\ 1 1 東北大学多元物質科学研究所， $\bar{T} 980-8577$ 仙台市青葉区片平 2-1-1. \\ 和東北大学大学院工学研究科附属エネルギー安全科学国際研究センター, T 980-8579 仙台市青葉区荒巻字青葉 6-6-11. \\ ${ }^{3} 3$ 東北大学大学院了学研究科, $\bar{T} 980-8579$ 仙台市青葉区荒巻字青葉 6-6-11.
}

\section{Evaluation of Elastic Property of $\left(\mathrm{CeO}_{2}\right)_{1-\mathrm{x}}\left(\mathrm{YO}_{1.5}\right)_{\mathrm{x}}$ Ceramics}

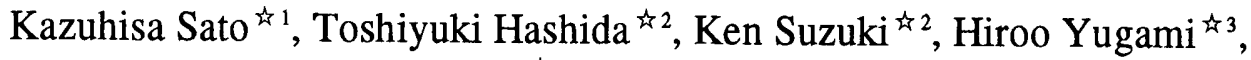 \\ Tatsuya Kawada ${ }^{\text {th } 1}$ and Junichiro Mizusaki ${ }^{\text {tr } 1}$
}

\footnotetext{
1nstitute of Multidisciplinary Research for Advanced Materials, Tohoku University, 2-1-1 Katahira, Aoba-ku, Sendai 980-8577.

${ }^{2}$ Fracture and Reliability Research Institute, Tohoku University, 6-6-11 Aza-Aoba, Aramaki, Aoba-ku, Sendai 980-8579.

${ }^{3}$ Graduate School of Engineering, Tohoku University, 6-6-11 Aza-Aoba, Aramaki, Aoba-ku, Sendai 980-8579.
}

Received July 13, 2005

\section{SYNOPSIS}

The influences of the sintering additive content of $\mathrm{Y}_{2} \mathrm{O}_{3}$ on elastic modulus of ceria ceramics were investigated by small punch (SP) testing method and molecular dynamics (MD) method. $\mathrm{Y}_{2} \mathrm{O}_{3}$ doped ceria powders with a composition of $\left(\mathrm{CeO}_{2}\right)_{1-\mathrm{x}}\left(\mathrm{YO}_{1.5}\right)_{\mathrm{x}}(\mathrm{x}=0,0.10,0.15,0.20,0.30,0.40)$ were prepared by a co-precipitation method. The powders were compacted by die pressing $(50 \mathrm{MPa})$ followed by cold isostatic pressing $(120 \mathrm{MPa})$, and sintered at $1500^{\circ} \mathrm{C}$ in air for $5 \mathrm{~h}$. The elastic modulus was decreased significantly with increasing additive contents of the $\mathrm{Y}_{2} \mathrm{O}_{3}$ oxides. Especially, it tended to exhibit a minimum value at $10 \sim 20 \mathrm{~mol} \%$. However, ionic conductivity increased with increasing additive content of the $\mathrm{Y}_{2} \mathrm{O}_{3}$ oxides, exhibited a maximum value at $15 \mathrm{~mol} \%$. Calculation model and interatomic potential were shown to be useful to evaluate the elastic property.

KEY WORDS

solid oxide fuel cell, ceria ceramics, elastic modulus, small punch (SP) testing method, molecular dynamics (MD) method

\section{1 緒 言}

固体酸化物型燃料電池 (Solid Oxide Fuel Cells, SOFCs) は高 温発電システム $\left(600^{\circ} \mathrm{C} \sim 1000^{\circ} \mathrm{C}\right)$ であり, マイクロガスター ビンと併用することにより発電効率を最大 $70 \%$ 程度まで向上 させることが可能である ${ }^{1,2}$. しかし，高い作動温度条件下で は，セルおよび周辺構成材料はセラミックス材に限定される ため，機械的特性における信頼性の低さが問題となる。そこ で，近年，周辺構成材料に金属が使用できる $600^{\circ} \mathrm{C} \sim 800^{\circ} \mathrm{C}$ まで作動温度を中・低温化することにより信頼性を向上させ る研究が行われている. 現在, 電解質の主流であるYSZ (Yttria Stabilized Zirconia)は，中・低温領域では十分な酸素イオン導 電性を保持しないことから必要な効率を得ることができない. そこで，中・低温領域でも高いイオン導電性を示す電解質材 料が開発されている. セリア系セラミックスは純セリアに希 土類酸化物を固溶することにより極めて高い酸素イオン導電 性を示すことが知られている3). そのため, セリア系セラミッ
クスは中・低温発電用電解質として期待されており，電気的 特性に関する多くの研究4-11)がなされている.しかしながら, 実用化するために重要な機械的特性に関する研究は系統的な 研究がなされていない，そこで，著者らはこれまで室温環境 下におけるセリア系セラミックスの機械的特性を系統的に評 価してきた ${ }^{12,13)}$. 本研究では高温環境下における $\left(\mathrm{CeO}_{2}\right)_{1-\pi}$ $\left(\mathrm{YO}_{1.5}\right)_{\mathbf{x}}$ の機械的特性評価をスモールパンチ(SP)法および分子 動力学 $(\mathrm{MD})$ 法を用いて行った.

\section{2 実験方法}

2.1 实験方法

本試験には，セリア系セラミックスを供した。所定量の $\mathrm{CeO}_{2}$ (純度 $99.9 \%$ ，阿南化成(侏製) に $\mathrm{Y}_{2} \mathrm{O}_{3}$ (純度 $99.9 \%$ ，阿南 化成(侏製)の金属酸化物を共沈法にて添加したセリア粉末を準 備した (以後, $\mathrm{YDC}$ と略記). 純 $\mathrm{CeO}_{2}$ に添加した $\mathrm{Y}_{2} \mathrm{O}_{3}$ の濃度 は $0,10,15,20,30,40 \mathrm{~mol} \%$ である. 
焼結体の縦弾性係数は小型試験法であるスモールパンチ (SP) 試験法 ${ }^{12,13)}$ を用いた. SP 試験は $25^{\circ} \mathrm{C} \sim 1000^{\circ} \mathrm{C}$ まで温度 設定が可能な高温低歪速度試験機を用いクロスヘッド速度 $0.1 \mathrm{~mm} / \mathrm{min}$ で実施した. 試験片は周辺単純支持し, 先端が球 状のパンチャーにより中央部に負荷を作用させた. 荷重線上 の変位は, $\mathrm{Al}_{2} \mathrm{O}_{3}$ 製ロッドを試験片裏面に接触させ, ロッドの 移動量を作動トランス型変位計で計測することにより求めた. 試験温度は $25^{\circ} \mathrm{C}, 600^{\circ} \mathrm{C}$ の 2 通りであり，炉内部に $\mathrm{Ar}$ ガスを 封入した状態で所定の温度まで $100^{\circ} \mathrm{C} / \mathrm{h}$ で昇温した後, 最低 2 時間保持してから実験を行った。

\section{2 計算方法}

YDC の結晶構造は, 螢石型面心立方構造の $\mathrm{CeO}_{2}$ をもとに 作製した. YDCでは $\mathrm{Y}^{3+}$ イオンが $\mathrm{Ce}^{4+}$ と置換して陽イオン格 子位置に入り, 電気的中性を維持するため酸素空孔が形成さ れる. 本研究で用いた構造は, $\mathrm{Y}_{2} \mathrm{O}_{3}$ の添加量を実験同様それ ぞれ, $10,15,20,30,40 \mathrm{~mol} \%$ とし, 各力チオンによる Ce の部 分置換と酸化物イオンの除去を電荷補償による空孔として一 致させることによってモデル化した. またこのカチオンの部 分置換はユニットセル内にランダムに行い, 酸素空孔の生成 はY-Yの隣になるように生成した.

MD計算は河村らが開発したMXDORTOプログラム ${ }^{14)}$ を用 いて行った. 原子間ポテンシャルには, Born-Mayer-Huggins (BMH) ポテンシャルと類似式である静電ポテンシャル, 近接 交換反発ポテンシャルからなる 2 体中心力ポテンシャルを採 用した (式 1).

$$
U_{i j}=\frac{Z_{i} Z_{j} e^{2}}{r_{i j}}+f_{0}\left(b_{i}+b_{j}\right) \exp \left(\frac{a_{i}+a_{j}-r_{i j}}{b_{i}+b_{j}}\right)-\frac{c_{i} c_{j}}{r_{i j}^{6}}
$$

ここで, $Z_{i}$ はイオンの電荷, $e$ は電気素量, $f_{0}$ は定数 $\left(f_{0}=1 \mathrm{kcal}\right.$ $\left.\mathrm{mol}^{-1} \AA^{-1}\right), r_{i j}$ は原子 $i$ と原子 $j$ の距離, $a, b$ および $c$ は各原子 の大きさと硬さを表す原子固有のパラメータである. パラ メー夕のうち, 電荷 $Z_{i}$ はイオン性を $85 \%$ と仮定して, Ce, Y, $\mathrm{O}$ に対して, 各々 $3.40,2.55,-1.70$ の值を用いた. 様々な固体 材料の結晶構造を再現するように経験的に決められた式(1)の ポテンシャルに対するパラメータをTable 1に示す. モデルは Inaba らが行った電気特性モデルを用いた ${ }^{15}$. 粒子数, 体積, 温度一定のNVTアンサンブルで, 一軸, 静水圧環境を模擬し た. 粒子数は約 4000 である. また, 体積および温度はスケー

Table 1 Potential Parameters used in the present study.

\begin{tabular}{ccccc}
\hline Ion & \multicolumn{4}{l}{ Parameter } \\
\cline { 2 - 5 } & $Z_{i}$ & $a(\mathrm{~nm})$ & $b(\mathrm{~nm})$ & $c\left(\mathrm{~J}^{0.5}(\mathrm{~nm})^{3} \mathrm{~mol}^{-0.5}\right)$ \\
\cline { 2 - 5 } $\mathrm{O}$ & -1.70 & 1.5678 & 0.0865 & 27.0 \\
$\mathrm{Ce}$ & 3.40 & 2.2628 & 0.2386 & 0 \\
$\mathrm{Y}$ & 2.55 & 2.0290 & 0.2050 & 0 \\
\hline
\end{tabular}

リング法で制御した. 一軸変形 ([100]方向)を行い, 横方向の 変形を固定し, $C_{11}$ および $C_{12}$ を決めた(Fig.1). $C_{11}=\sigma_{x x} / \varepsilon_{x x} C_{12}$ $=\sigma_{y y} / \varepsilon_{x x}$ である. $\sigma_{x x} \sigma_{y y}$ および $\sigma_{z z}$ は変形によって生じる応力 で以下のように表される ${ }^{10}$.

$$
\begin{aligned}
& \sigma_{x x}=\frac{1}{A} \sum_{i<j} \frac{F\left(r_{i j}\right)}{r_{i j}}\left(\Delta x_{i j}\right)^{2}, \\
& \sigma_{y y}=\frac{1}{A} \sum_{i<j} \frac{F\left(r_{i j}\right)}{r_{i j}}\left(\Delta y_{i j}\right)^{2}, \\
& \sigma_{z z}=\frac{1}{A} \sum_{i<j} \frac{F\left(r_{i j}\right)}{r_{i j}}\left(\Delta z_{i j}\right)^{2},
\end{aligned}
$$

ここで, $A$ は格子の面積, $r_{i j}$ と $F\left(r_{i j}\right)$ はそれぞれ原子 $i$ から $j$ の 距離と力を表す. また, $\varepsilon_{x x}$ はひずみで $\varepsilon_{x x}=\left(b o x\left(x-b o x\left(x_{0}\right)\right)\right)$ $b o x\left(x_{0}\right)$ と表される. $b o x\left(x_{0}\right)$ および $b o x(x)$ はそれぞれ変形前と 変形後の格子一辺の長さを表す. 本計算においてひずみ $\varepsilon_{x x}$ は $0 \sim 0.002$ とした.

\section{3 結果および考察}

本研究で検討した $\left(\mathrm{CeO}_{2}\right)_{1-\mathrm{x}}\left(\mathrm{YO}_{1.5}\right)_{\mathrm{x}}$ の X 線回折図を Fig.2 に 示す. $\mathrm{Y}_{2} \mathrm{O}_{3}$ の添加量に関わらず全ての試料において, 立方晶 蛍石型特有の回折パターンとなっており, 単一相であること を確認した. また, $\mathrm{X}$ 線回折の結果より求めた格子定数も $\mathrm{Y}_{2} \mathrm{O}_{3}$ の添加量に対して直線的に変化していることから，本研究で 共沈法により作製した試料は $40 \mathrm{~mol} \%$ までの範囲内において 固溶体を形成しているものと考えられる.

続いて作製した固溶体を用いてSP試験法により縦弾性係数

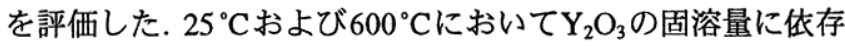
せずYDCの破壊は全て脆性的であった. Fig.3にSP試験で得

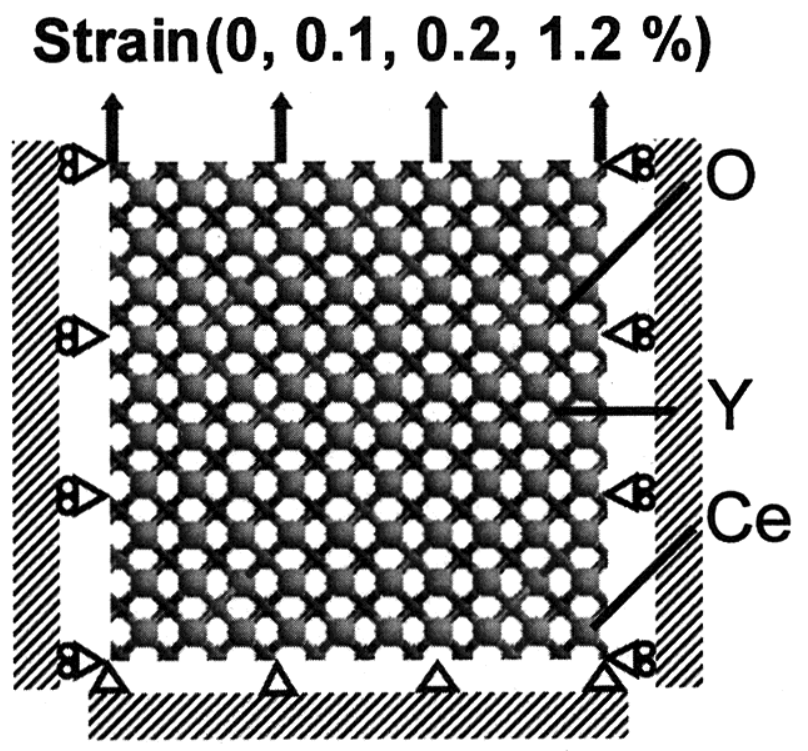

Fig.1 The calculation model of $\left(\mathrm{CeO}_{2}\right)_{1-\mathrm{x}}\left(\mathrm{YO}_{1.5}\right)_{\mathrm{x}}$. 


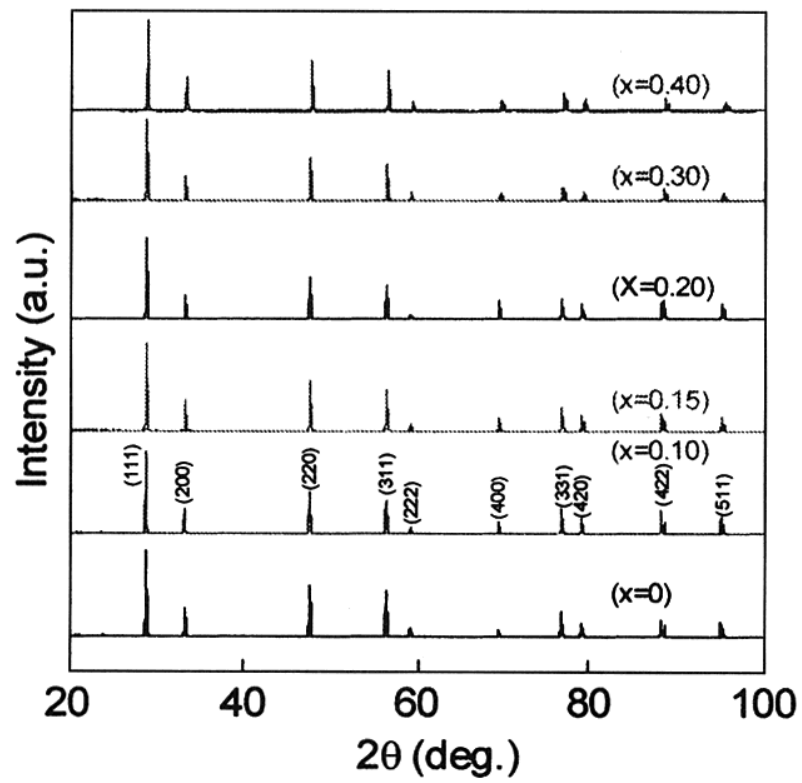

Fig.2 X-ray diffraction pattern of $\left(\mathrm{CeO}_{2}\right)_{1-\mathrm{x}}\left(\mathrm{YO}_{1.5}\right)_{\mathrm{x}}$.

られた $25^{\circ} \mathrm{C}$ および $600^{\circ} \mathrm{C}$ における YDC の縦弾性係数 $\mathrm{E}_{\mathrm{SP}}$ と $\mathrm{Y}_{2} \mathrm{O}_{3}$ の添加量の関係を示す. また, 二端子法により求めた 600 ${ }^{\circ} \mathrm{C}$ におけるイオン導電率と $\mathrm{Y}_{2} \mathrm{O}_{3}$ の添加量の関係も併せて示 す. $\mathrm{E}_{\mathrm{SP}}$ は試験温度に依存せず $\mathrm{Y}_{2} \mathrm{O}_{3}$ を純 $\mathrm{CeO}_{2}$ に添加すること により低下し, 添加量 $15 \sim 20 \mathrm{~mol} \%$ で極小値を示した後, 上 昇する傾向が観察された. イオン導電率は縦弾性係数とは反 対に, 希土類酸化物の添加量の増加とともに上昇し, $15 \mathrm{~mol} \%$ で極大值を示した後に，低下することが観察された．温度の 上昇とともにイオン導電率は上昇するが $700^{\circ} \mathrm{C}, 800^{\circ} \mathrm{C}$ におい ても $600^{\circ} \mathrm{C}$ とほぼ同じ傾向が見られた. これにより, YDCに 関しては電気的特性と弹性特性が負の相関にあることがわ かった.

そこで, これまで行われているイオン伝導モデルを用いて 縦弾性係数の予測ができるかを検証するために分子動力学計 算を行った. $C_{11}$ および $C_{12}$ をもとに以下の式から体積弾性率 $B$ および縦弾性係数 $E$ を求めた ${ }^{17}$. また, ここではポアソン比 は 0.33 とした ${ }^{8}$.

$$
\begin{aligned}
& B=\frac{C_{11}+2 C_{12}}{3} \\
& E=3(1-2 v) B
\end{aligned}
$$

$600^{\circ} \mathrm{C}$ における YDC の縦弾性係数の計算結果を SP 法によっ て求めた実験值と比較してFig.4に示す.酸素イオン導電率同 様, グラフは $\left(\mathrm{CeO}_{2}\right)_{0.9}\left(\mathrm{YO}_{1.5}\right)_{0.1}$ の縦弾性俰数 $\mathrm{E}_{10 \mathrm{YDC}}$ の実験值お よび計算值で規格化したものである. 計算値, 実験值ともに $\mathrm{Y}_{2} \mathrm{O}_{3}$ を $20 \mathrm{~mol} \%$ 添加した組成で縦弹性係数は最小値を示し， 定性的に一致した. これより, 本計算に用いたモデルおよび イオン間ポテンシャルは縦弾性係数を予測するのに妥当であ ることがわかった.

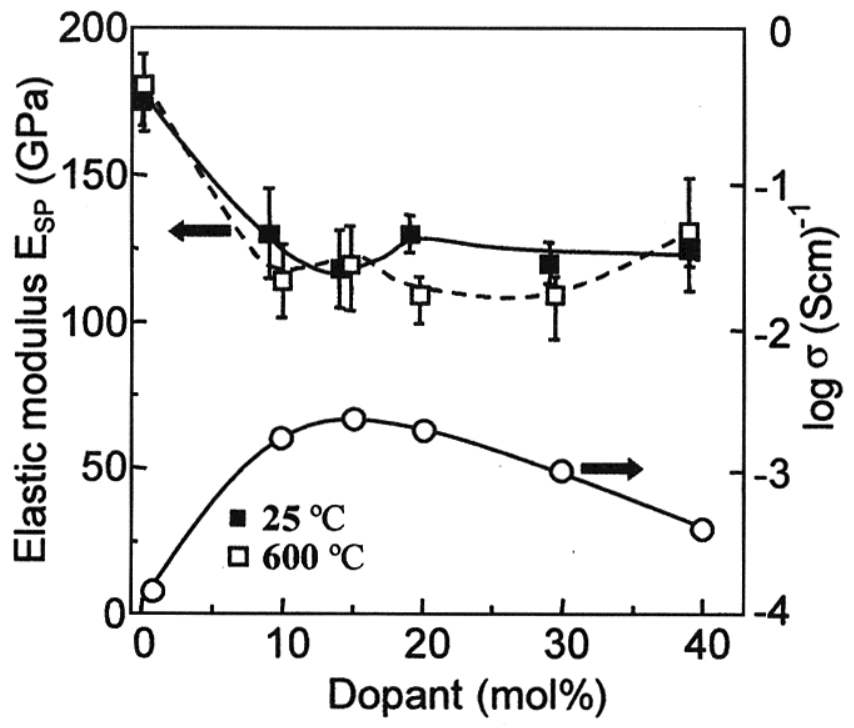

Fig.3 Elastic modulus $E_{S P}$ and ionic conductivity $\sigma$ of $\left(\mathrm{CeO}_{2}\right)_{1-\mathrm{x}}$ $\left(\mathrm{YO}_{1.5}\right)_{\mathrm{x}}$ as a function of the dopant content.

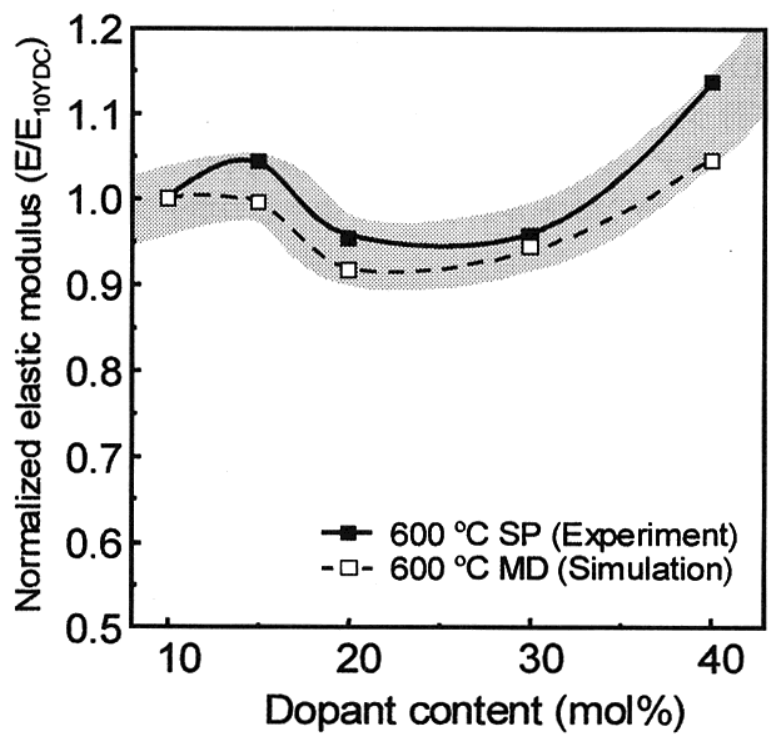

Fig.4 Normalized elastic modulus of $\left(\mathrm{CeO}_{2}\right)_{1-\mathrm{x}}\left(\mathrm{YO}_{1.5}\right)_{\mathrm{x}}$ as a function of the dopant content (SP method and MD method).

この計算結果を基に, $\mathrm{Y}_{2} \mathrm{O}_{3}$ 添加によるYDCの縦弾性係数の 変化メカニズムの検討を行った.

一般的に材料内部に空孔などの欠陥が存在すると完全緻密 な材料に比べて低い弹性特性を示す ${ }^{18}$. 本来であれば希土類 酸化物の添加量の増大に伴い酸素空孔のミクロ欠陥が増加す るので縦弾性係数は低下する. それに対して, 本研究で用い た YDC は $\mathrm{Y}_{2} \mathrm{O}_{3}$ の添加量が $30 \mathrm{~mol} \%$ 以降，縦弾性係数が上昇 する傾向が見られた.これは, $\mathrm{Y}_{2} \mathrm{O}_{3}$ の添加により材料内の剛 性が局所的に高くなったことが原因であると予想される.

そこで, $\mathrm{Y}_{2} \mathrm{O}_{3}$ 添加による原子間の距離の変化について検討 


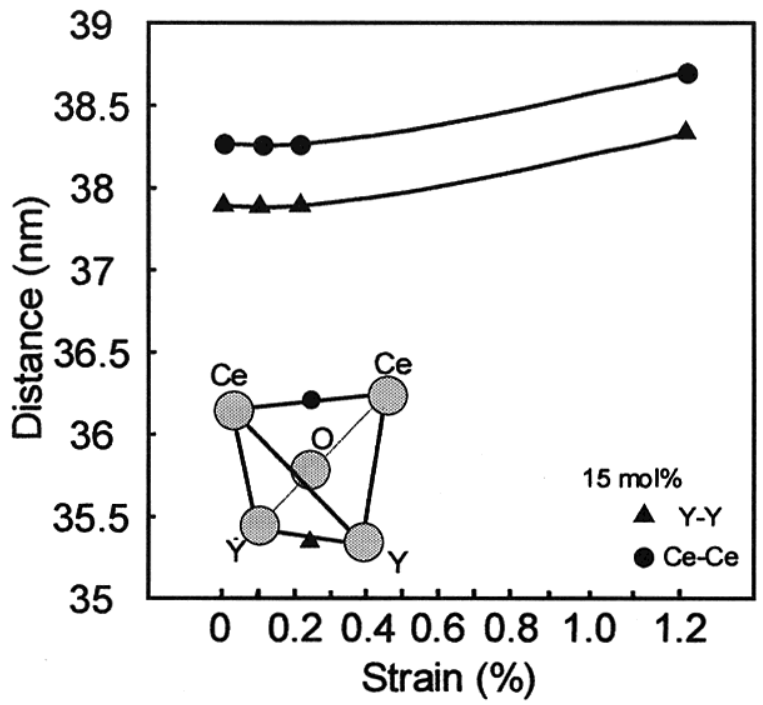

Fig.5 Distance of cation as a function of the strain (15 mol\%).

した. $\mathrm{Y}_{2} \mathrm{O}_{3}$ を添加してセルにひずみを加えた場合に生じるカ チオン同士の距離の変化を Fig.5 およびFig.6に示す. $\mathrm{Y}_{2} \mathrm{O}_{3}$ を $15 \mathrm{~mol} \%$ 添加した場合の Ce-CeおよびY-Y間の距離はそれぞ れ $38.2 \mathrm{~nm}, 37.8 \mathrm{~nm}$ であった. 1.2\%ひずみを加えることにより Y-Y, Ce-Ceそれぞれ, $38.7 \mathrm{~nm}, 38.3 \mathrm{~nm}$ まで伸びた (Fig.4). 40 $\mathrm{mol} \%$ 添加した場合，無ひずみで Ce-Ce およびY-Y 間の距離 はそれぞれ $37.8 \mathrm{~nm}, 37.0 \mathrm{~nm}$ でカチオン間の距離が $15 \mathrm{~mol} \%$ に 比べて $2 \%$ 以上も短くなった (Fig.5). $15 \mathrm{~mol} \%$ では, Ce-Ce, Y-Y 間の距離の差は, $0.4 \mathrm{~nm}$ であるのに対し, $40 \mathrm{~mol} \%$ では $0.8 \mathrm{~nm}$ となっており, $\mathrm{Y}_{2} \mathrm{O}_{3}$ の添加量を増やすことにより材料内部に 局所的なひずみが生じていることがわかった. また, $\mathrm{Ce}-\mathrm{Ce}$ の 距離は $0.1 \%$ のびみを加えた段階で $15 \mathrm{~mol} \%$ のそれと同等の 值を示すことになるが, これは, $\mathrm{Y}_{2} \mathrm{O}_{3}$ 添加により初期にひず んだ Ce-Ceが元の状態に戻ったと考えられる. ただし，それ 以降の伸びはCe-CeおよびY-Y ともほとんび伸びず, $\mathrm{Y}_{2} \mathrm{O}_{3}$ の 添加によりカチオン間, 特にY-Y間の結合が強化された. つ まり，変形しにくくなったことがわかる. したがって, $\mathrm{Y}_{2} \mathrm{O}_{3}$ 添加量が多い組成では, Y-Y の絶対量が増えて, 弾性率が増 加すると考えられる. 縦弹性係数は $\mathrm{Y}_{2} \mathrm{O}_{3}$ 添加量増加による酸 素空孔の増大と, カチオン間の結合の増加によるトレードオ フ効果によりピークがあるものと考えられる.

\section{4 結 言}

本研究ではセリア系セラミックスの縦弾性係数に及ぼす希 土類酸化物の影響について $\mathrm{Y}_{2} \mathrm{O}_{3}$ を添加物の対象として用い， 添加量を系統的に変化させて検討した. SP試験法とMD法を 用いて縦弹性係数の評価を行った. 以下に得られた知見を示す.

(1) 純 $\mathrm{CeO}_{2}$ に $\mathrm{Y}_{2} \mathrm{O}_{3}$ を添加することにより, $40 \mathrm{~mol} \%$ までの範 囲内で $\mathrm{CeO}_{2}$ 固溶体を作製することができた.

(2) 縦弹性係数は, $\mathrm{Y}_{2} \mathrm{O}_{3}$ を添加することにより, 純 $\mathrm{CeO}_{2}$ に対 して低下する傾向が観察された. 特に添加量が $10 \sim 20$

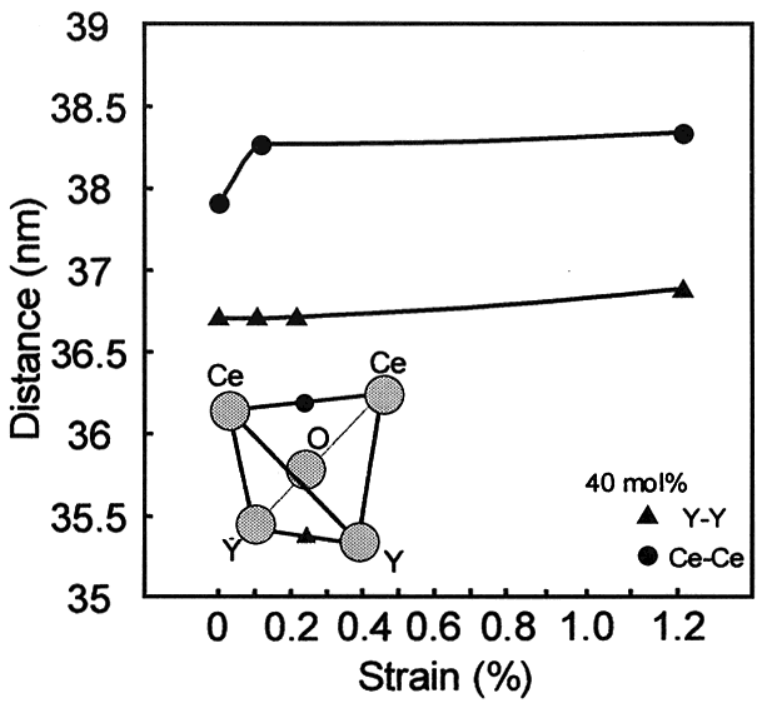

Fig.6 Distance of cation as a function of the strain ( $40 \mathrm{~mol} \%)$.

mol\%で最も小さな值を与える傾向を示した. 反対にイオ ン導電率は増加する傾向が見られ, $15 \mathrm{~mol} \%$ で最大値を示 した.

(3) $\mathrm{MD}$ 法により, 縦弾性係数の $\mathrm{Y}_{2} \mathrm{O}_{3}$ の添加量に対する変化 挙動が評価でき,本研究で用いたモデルおよびイオン間ポ テンシャルの妥当性を示すことができた.

(4) $\mathrm{Y}_{2} \mathrm{O}_{3}$ の添加量の増加に伴い, カチオン, 特に $\mathrm{Y}-\mathrm{Y}$ 間が変 形しにくいことがわかった. また, 一定のひずみに対して Yの多い領域では高い応力が発生することがわかり, 局所 的に剛性が高くなることがわかった. 縦弾性係数は酸素空 孔が増加すると低くなると考えられるため, $\mathrm{Y}_{2} \mathrm{O}_{3}$ の添加 量の増加に伴い低下する. したがって，このトレードオフ 効果により酸素イオン導電率同様, 縦弾性係数も極值があ るものと考えられる.

実験および計算の結果より, セリア系セラミックスにおい ては, 電気的特性と機械的特性の両立が難しいことがわかっ た. そのため, セリア系セラミックスを使用する場合, 使用 条件を十分検討して設計する必要があることがわかる. また, 分子動力学法を用いて, 電気的特性のみならず，機械的特性 の予測も可能であることがわかった

\section{謝 辞}

本研究は, 文部科学省科学研究費補助金特定領域研究「高 温ナノイオニクスを基盤とするへテロ界面制御フロンティア」 (課題番号 439), 21 世紀 COE プログラム「ナノテクノロジー 基盤機械科学フロンティア」および「流動ダイナミクス国際 研究教育拠点」の支援を受けて行われたものです.

\section{文献}

1) N.Q.Minh: "Ceramic Fuel Cells", J. Am. Ceram. Soc., 76(1993) 563-588. 
2) S.C.Singhal: "Advances in solid oxide fuel cell technology", Solid State Ionics, 135(2000)305-313.

3) H.Inaba et al.: "Ceria-based solid electrolytes", Solid State Ionics, 83(1996)1-16.

4) M.Mogensen et al.: "Physical, chemical and electrochemical properties of pure and doped ceria", Solid State Ionics, 129(2000) 63-94.

5) H.Yahiro et al.: "Electrical properties and reducibilities of ceriarare earth oxide systems and their application to solid oxide fuel cell", Solid State Ionics, 36(1989)71-75.

6) C.Tian et al.: "Ionic conductivities, sintering temperatures and microstructures of bulk ceramic $\mathrm{CeO}_{2}$ doped with $\mathrm{Y}_{2} \mathrm{O}_{3}{ }^{\prime \prime}$, Solid State Ionics, 134(2000)89-102.

7) S.Sameshima et al.: "Thermal and mechanical properties of rare earth-doped ceria ceramics", Material Chemistry and Physics, 61(1999)31-35.

8) A.Atkinson and A.Selcuk: "Mechanical behaviour of ceramic oxygen ion-conducting membranes", Solid State Ionics, 134 (2000)59-66.

9) N.Sammes et al.: "The Structural and Mechanical Properties of $\left(\mathrm{CeO}_{2}\right)_{1-\mathrm{x}}\left(\mathrm{Gd}_{2} \mathrm{O}_{3}\right)_{\mathrm{x}}$ Electrolytes", DENKI KAGAKU, 64(1996) 674-680.

10) J.Van Herle et al.: "Concept and technology of SOFC for electric vehicles", Solid State Ionics, 132(2000)333-342.

11) O.Bellon et al.: "Mechanical properties and electrochemical characterisation of extruded doped cerium oxide for use as an electrolyte for solid oxide fuel cells", Journal of Power Sources, 75(1998)116-121.

12) K.Sato, H.Yugami and T.Hashida: "'Evaluation of the Effect of Rare-earth Oxides on Fracture Properties of Ceria Ceramics by Small Specimen Method", Transactions of the Japan Society of Mechanical Engineers, Vol.70, No.690(2004)321-326.

13) K.Sato, H.Yugami and T.Hashida: "Effect of Rare-earth Oxides on Fracture Properties of Ceria Ceramics", Journal of Materials Science, 39(2004)5765-5770.

14) K.Kawamura, F.Yonezawa Editor, Molecular Dynamics Simulations Springer, Berlin, (1992)p.88.

15) H.Inaba et al.: "Molecular dynamics simulation of gadoliniadoped ceria", Solid State Ionics, 122(1999)95-103.

16) W.Sekkal et al.: "Molecular Dynamics simulations of uniaxial and hydrostatic compression of $\mathrm{C} 70$ in the disordered phase", Computational Materials Science, 9(1998)295-302.

17) D.J.Green: An Introduction to the Mechanical Properties of Ceramics, Cambridge University Press, Cambridge, (1998)p. 87.

18) J.D.Eshelby: Proc. Roy. Soc., 241A(1957)376-380. 